\title{
Foreign currency loan conversions and currency mismatches
}

Andreas M. Fischer, Pınar Yeşin

SNB Working Papers

$4 / 2019$ 


\section{DISCLAIMER}

The views expressed in this paper are those of the author(s) and do not necessarily represent those of the Swiss National Bank. Working Papers describe research in progress. Their aim is to elicit comments and to further debate.

\section{COPYRIGHT $\odot$}

The Swiss National Bank (SNB) respects all third-party rights, in particular rights relating to works protected by copyright (information or data, wordings and depictions, to the extent that these are of an individual character).

SNB publications containing a reference to a copyright (C) Swiss National Bank/SNB, Zurich/year, or similar) may, under copyright law, only be used (reproduced, used via the internet, etc.) for non-commercial purposes and provided that the source is mentioned. Their use for commercial purposes is only permitted with the prior express consent of the SNB.

General information and data published without reference to a copyright may be used without mentioning the source. To the extent that the information and data clearly derive from outside sources, the users of such information and data are obliged to respect any existing copyrights and to obtain the right of use from the relevant outside source themselves.

\section{LIMITATION OF LIABILITY}

The SNB accepts no responsibility for any information it provides. Under no circumstances will it accept any liability for losses or damage which may result from the use of such information.

This limitation of liability applies, in particular, to the topicality, accuracy, validity and availability of the information.

ISSN 1660-7716 (printed version)

ISSN 1660-7724 (online version)

(c) 2019 by Swiss National Bank, Börsenstrasse 15,

P.O. Box, $\mathrm{CH}-8022$ Zurich 


\title{
Foreign currency loan conversions and currency mismatches*
}

\author{
Andreas M. Fischer ${ }^{\dagger} \quad$ Pinar Yeşin ${ }^{\ddagger}$
}

July 2019

\begin{abstract}
This paper examines the effect of currency conversion programs from Swiss franc-denominated loans to other currency loans on currency risk for banks in Central and Eastern Europe (CEE). Swiss franc mortgage loans proliferated in CEE countries prior to the financial crisis and contributed to the volume of non-performing loans as the Swiss franc strongly appreciated during the post-crisis period. Empirical findings suggest that Swiss franc loan conversion programs reduced currency mismatches in Swiss francs but increased currency mismatches in other foreign currencies in individual countries. This asymmetric effect of conversion programs arises from the loan restructuring from Swiss francs to a non-local currency and the high level of euro mismatches in the CEE banking system.
\end{abstract}

Keywords: Loan conversion programs, emerging markets, currency mismatch

JEL Classification: F15, F21, F32, F36, G15

\footnotetext{
*The authors would like to thank Alin Andrieş, Martin Brown, Dániel Palotai, Tomislav Ridzak, and Előd Takáts; seminar participants at the Bank for International Settlements, the International Monetary Fund, the World Trade Institute at the University of Berne, the University of Zurich, and the Swiss National Bank; and conference participants at the 25th Dubrovnik Economic Conference for helpful discussions and constructive comments. Henrike Groeger, Chloe Larkou, Anna Raafat, and Amalia Repele provided valuable research assistance. Any remaining errors are our own. The views expressed in this paper are those of the authors and not necessarily those of the Swiss National Bank.

${ }^{\dagger}$ Swiss National Bank and CEPR. Boersenstrasse 15, PO Box, CH 8022, Switzerland. andreas.fischer@snb.ch.

${ }^{\ddagger}$ Corresponding author. Swiss National Bank. Boersenstrasse 15, PO Box, CH 8022, Switzerland. pinar.yesin@snb.ch.
} 


\section{Introduction}

When the Swiss National Bank (SNB) discontinued its policy of the minimum exchange rate of 1.2 Swiss francs against the euro on January 15, 2015, hundreds of thousands of holders of Swiss franc mortgages across Central and Eastern Europe (CEE) suddenly found themselves facing higher loan repayments of up to $20 \%$. The sharp appreciation of the Swiss franc augmented the number of nonperforming loans and increased the credit risk of bank balance sheets. To undo the burden of further currency shocks, many CEE countries looked to the Hungarian experience of converting Swiss franc mortgage loans to domestic currency loans two months prior to the SNB's discontinuation of the exchange rate floor. Croatia, Cyprus, Montenegro, Romania, and Serbia followed with similar conversion programs from Swiss franc-denominated loans to other currencies, hereinafter referred to as loan conversion programs. In these programs, households had the choice of converting their Swiss franc mortgage loans to another currency (such as the domestic currency or the euro, i.e., another foreign currency) or maintaining their mortgage loans in Swiss francs.

In this paper, we examine the effect of loan conversions from Swiss francs to other currencies on measures of systemic exchange rate risks to bank balance sheets in CEE. Although households with Swiss franc mortgages benefited from loan conversion programs by reducing their foreign currency exposure, it is unclear whether the same programs were as effective in reducing systemic exchange rate risks to bank balance sheets. Many CEE banks outside the euro area suffer from dual currency mismatches in euros and in Swiss francs. Because some loan conversion programs converted Swiss franc loans into euro loans rather than into domestic currency loans, the reduction of aggregate systemic risks for CEE banks is ambiguous.

Undoing Swiss franc-denominated mortgage loans in CEE has numerous ram- 
ifications for macroeconomic and macroprudential policy. However, a key benefit of loan conversions for the financial system is the reduction of the exposure of CEE banks to systemic exchange rate risks to their balance sheets through domestic currency depreciations. ${ }^{1}$ Ranciere et al. (2010b) and Reinhart et al. (2014) state that currency mismatch has been one of the key vulnerabilities leading to crises in emerging economies (i.e., Mexico in 1994, East Asia in 1997, and CEE in 2008). Large currency mismatches between foreign currency denominated assets and foreign currency denominated liabilities suggest that exchange rate risk could contribute to systemic risk in the CEE banking sector. ${ }^{2}$ This is particularly the case if borrowers of foreign currency denominated loans are unable to hedge their exchange rate risk, meaning that a large proportion of borrowers of foreign currency loans will not be able to service their loans and will default after a large devaluation. Such an increase in the number of non-performing bank loans could dramatically affect the banking system's capital base and have systemic implications for the economy.

Our empirical analysis identifies the effect of loan conversion programs on currency mismatch indexes in Swiss francs and in other foreign currencies separately. Following Ranciere et al. (2010a) and Yeşin (2013), we use a currency mismatch measure defined as the ratio of foreign currency denominated net unhedged liabilities to total bank assets. The main feature of this measure is that it adjusts the banks' net foreign currency liabilities by subtracting from the asset side foreign currency loans to households (and firms) without foreign currency income. This measure takes into account bank exposure to credit risk through sharp depreciations in the domestic currency.

\footnotetext{
${ }^{1}$ The ECB (2015a) has stated on several occasions that foreign currency loans represent a major risk to financial stability in several member states where the share of foreign currency loans is relatively high. See also ECB (2015b), where they note that the conversion program is expected to provide relief for distressed foreign currency borrowers.

${ }^{2}$ See, for example, Andrieş and Nistor (2018) regarding bank exposure to currency risk.
} 
The main empirical findings suggest that Swiss franc loan conversions lowered the systemic exchange rate risk in Swiss francs for bank balance sheets in CEE. Large reductions in Swiss franc loan volumes on banks' balance sheets, however, did not always result in a reduction in currency mismatches in other foreign currencies. In several cases, the specifics of the loan conversion matter; hence it is difficult to offer a range of stylized facts about loan conversion programs. When loan conversion programs restructured household mortgages from Swiss francs to euros, then the level of euro mismatches increased for CEE banks.

Our new empirical findings on the effects of loan conversions contribute to three strands of the post-financial crisis literature for emerging markets. The first strand of the literature focuses on the prevalence of foreign currency loans in CEE; see Brown and de Haas (2012), Brown et al. (2011), Fidrmuc et al. (2013), and Temesvary (2016). ${ }^{3}$ This literature has primarily focused on identifying motives and risks behind the buildup of foreign currency loans on the part of both households and banks. Our analysis adds a new dimension to the credit growth narrative in CEE, in that it concentrates on the rapid undoing of foreign currency loans and their effects on bank balance sheet risks linked to foreign currency exposure.

The second strand of literature to which our paper contributes concerns international shocks and their transmission effects on emerging market countries. This literature has primarily focused on the international transmission of monetary policy shocks from the largest economies. Banerjee et al. (2016), Bernanke (2015), Canova (2005), Di Giovanni and Shambaugh (2008), Georgiadis (2016), and Miniane and Rogers (2007) consider the transmission of U.S. shocks. These studies emphasize the nature of the exchange rate regime, the level of trade integration, or financial integration as important factors in explaining the transmission of the

\footnotetext{
${ }^{3}$ Some of this literature on foreign currency denominated loans has focused solely on developments in Swiss franc-denominated loans. See, for example, Albacete and Lindner (2015), Andrieş et al. (2017), Auer et al. (2012), Beckmann and Stix (2015), Beer et al. (2010), and Yeşin (2013).
} 
monetary policy shock. On the other hand, Qureshi et al. (2011) examine the effectiveness of policy responses in terms of macroprudential policies and capital controls in mitigating financial stability risks associated with spillovers. We add to this international spillover literature by examining policy responses of loan conversions to international monetary policy shocks from a small open economy (i.e., the SNB's decision to discontinue the minimum exchange rate policy) with a high level of financial integration (i.e., Swiss franc mortgage loans).

Our analysis of loan conversions also contributes to a third strand of literature on de-dollarization. In a low-inflation environment, it is commonly recognized that dollarization impedes the transmission of monetary policy. Luca and Petrova (2008) and Acosta-Ormaechea and Coble (2011) argue that deepening domestic financial markets or introducing macroprudential measures supports the de-dollarization process. Additional reform measures, such as restrictions on foreign currency lending, have been introduced in various countries to accelerate the de-dollarization process. At the same time, Catão and Terrones (2016), De Nicolò and Lucchetta (2009), and Rennhack and Nozaki (2006) hold the view that de-dollarization requires restoring the domestic currency to its function as a trustworthy unit for saving and intermediation. However, dollarization has often proven to be highly persistent, even when macroeconomic stability has been achieved. ${ }^{4}$ We add to these case studies by considering the effect of a specific instrument (i.e., loan conversions) that is designed to rapidly undo mortgage loans denominated in Swiss francs in countries that also suffer from a high level of euroization. ${ }^{5}$

\footnotetext{
${ }^{4}$ See the discussion in Ize and Levy-Yeyati (2003), Reinhart et al. (2014), and Galindo and Leiderman (2005).

${ }^{5}$ It should be further emphasized that the case of foreign denominated loans in Swiss francs does not fit the stylized facts highlighted for foreign denominated loans in U.S. dollars described in Gopinath and Stein (2018). They note the importance of trade invoicing and the high level of financial integration that supports the issuance of foreign denominated loans in U.S. dollars. Neither of these feature apply for the Swiss franc.
} 
This paper is organized as follows. Section 2 discusses the loan conversion programs within the context of foreign currency lending in CEE. Section 3 presents the mismatch measure used in the empirical analysis. Section 4 discusses the empirical framework. Section 5 presents empirical results comparing the relative behavior of currency mismatch indexes in Swiss francs and other foreign currencies. Section 6 concludes.

\section{Recent experiences with Swiss franc loan conver- sions}

This section highlights the main features of loan conversion programs intended to reduce the exposure of household mortgage borrowers and bank lenders in Hungary, Croatia, and Romania to Swiss franc exchange rate movements. ${ }^{6}$ The next subsection highlights the main motives for introducing loan conversion programs. This is followed by a second subsection that addresses country-specific features of loan conversion programs.

\subsection{Core issues behind loan conversion programs}

Swiss franc loan conversions were considered a policy option after a series of financial and macroprudential measures had been introduced to stem the demand for foreign currency denominated loans in various CEE countries. These measures included restrictions on the ability of households and small firms to receive new loans denominated in foreign currency, tighter lending requirements on the part of banks, higher capital requirements for banks for existing loans, and stringent rules for banks to reduce maturity and currency mismatches on their balance sheets. ${ }^{7}$

\footnotetext{
${ }^{6}$ Although conversion programs took place in many CEE countries, our focus is on the three largest programs implemented in Hungary, Croatia, and Romania.

${ }^{7}$ Fischer and Yeşin (2016) provide a descriptive overview of these macroprudential measures. See also ECB (2014).
} 
However, these measures could not entirely reverse foreign currency lending or eliminate the risks associated with foreign currency loans.

The SNB's discontinuation of the minimum exchange rate policy revealed that households and banks in CEE were still exposed to currency risk, despite the introduction of various macroprudential policies. ${ }^{8}$ Figure 1 shows that the appreciation of the Swiss franc in January 2015 affected CEE countries strongly, though exchange rates between the domestic currency and the Swiss franc depreciated more over time in countries that undertook loan conversions (i.e., Hungary, Croatia, and Romania) than in the remaining CEE countries in our sample that did not introduce loan conversion programs (i.e., Austria, Bulgaria, Czech Republic, Estonia, Serbia, and Slovenia).

Figure 1: Average exchange rates of conversion and non-conversion countries per CHF (2010:Q1=100)

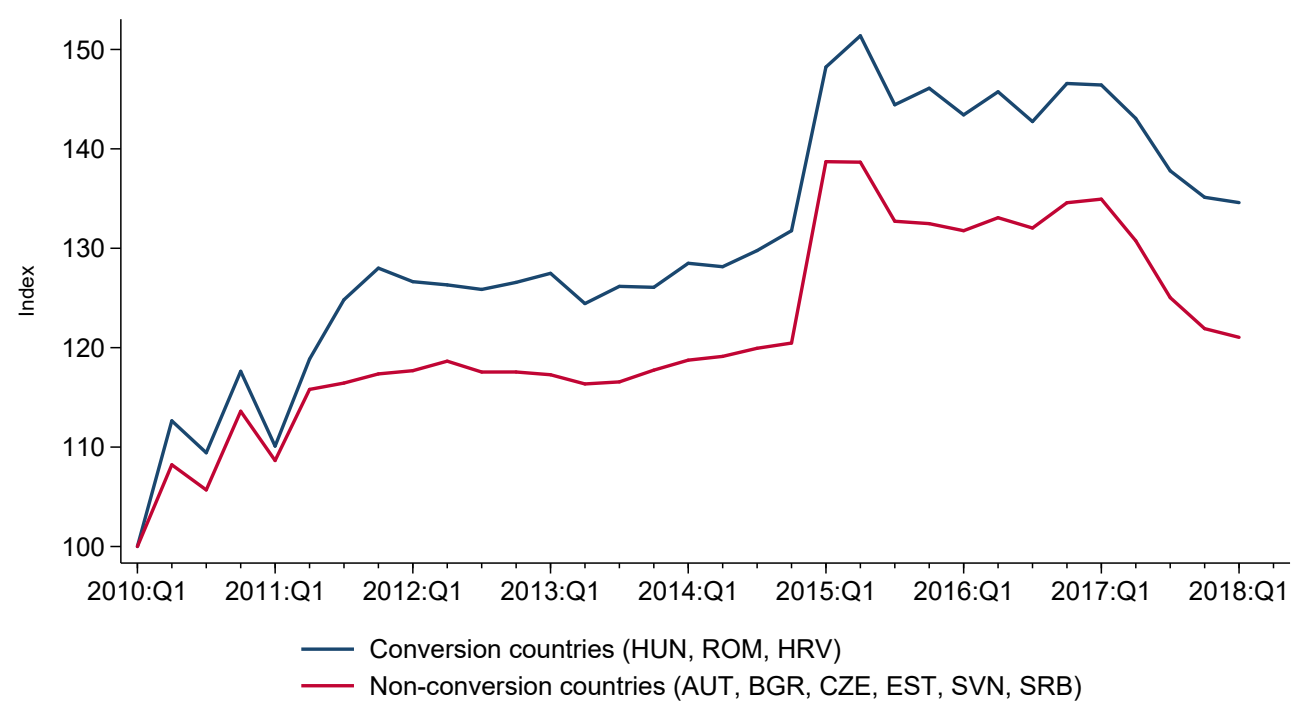

Source: Reuters and authors' calculations

\footnotetext{
${ }^{8}$ See Auer et al. (2018) and Bonadio et al. (2019) for a detailed discussion of the exchange rate shock linked to the discontinuation announcement of the minimum exchange rate policy.
} 
Furthermore, the timing of the conversions was also facilitated by low domestic and international interest rates. The reduced spread between domestic and Swiss interest rates, shown in Figure 2, lowered the attractiveness of Swiss franc loans. Figure 3 shows that non-performing loans were higher in conversion countries than in the remaining CEE countries in our sample that did not implement loan conversion programs.

Figure 2: Average interest rate spread between Swiss franc and domestic currency of CEE countries

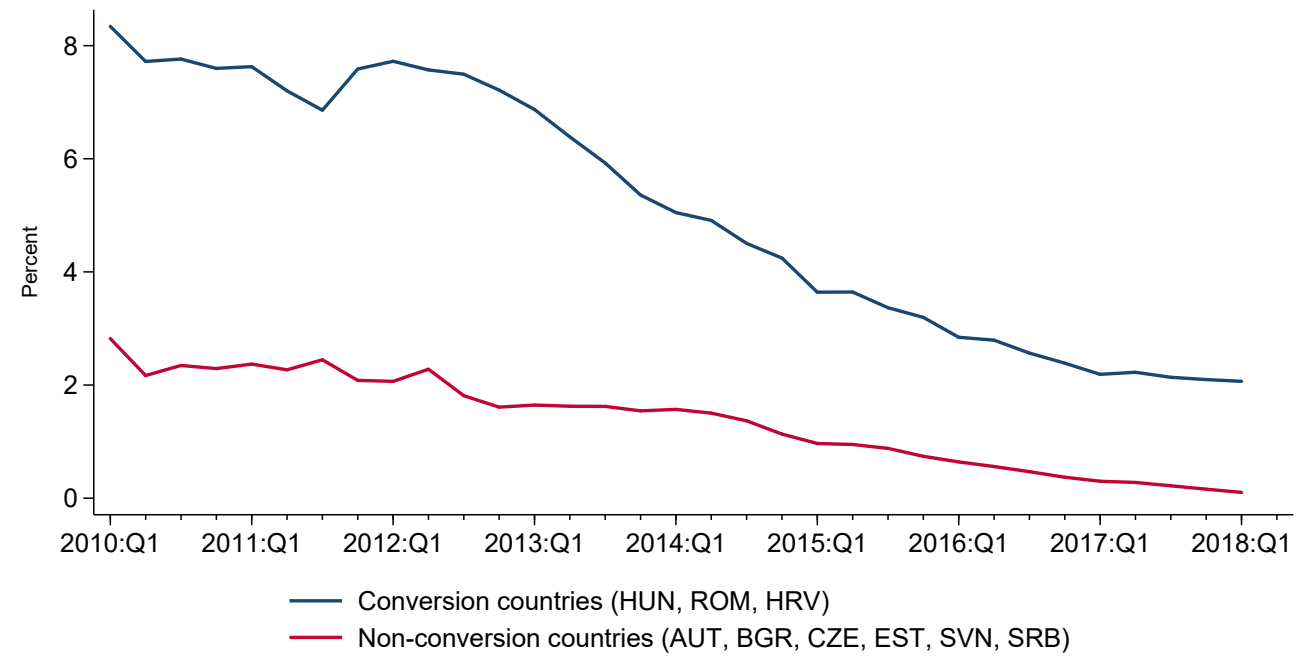

Note: Data for Slovenia starts in 2010:Q2 and for Serbia in 2010:Q3

Source: Datastream, central banks, and authors' calculations

The rapid build-up of Swiss franc mortgage loans in CEE in the period prior to the financial crisis was followed by a steady decline in loan volumes in the post-crisis period. Figures 4 and 5 show loan volumes in Swiss francs in countries with loan conversion programs and those without loan conversion programs. A notable difference between the two figures is that the Swiss franc loan volumes are larger in countries with loan conversion programs. ${ }^{9}$ A further difference is

\footnotetext{
${ }^{9}$ Poland, which has the largest outstanding volume of Swiss franc denominated mortgage
} 
Figure 3: Average bank non-performing loans to total gross loans of CEE countries

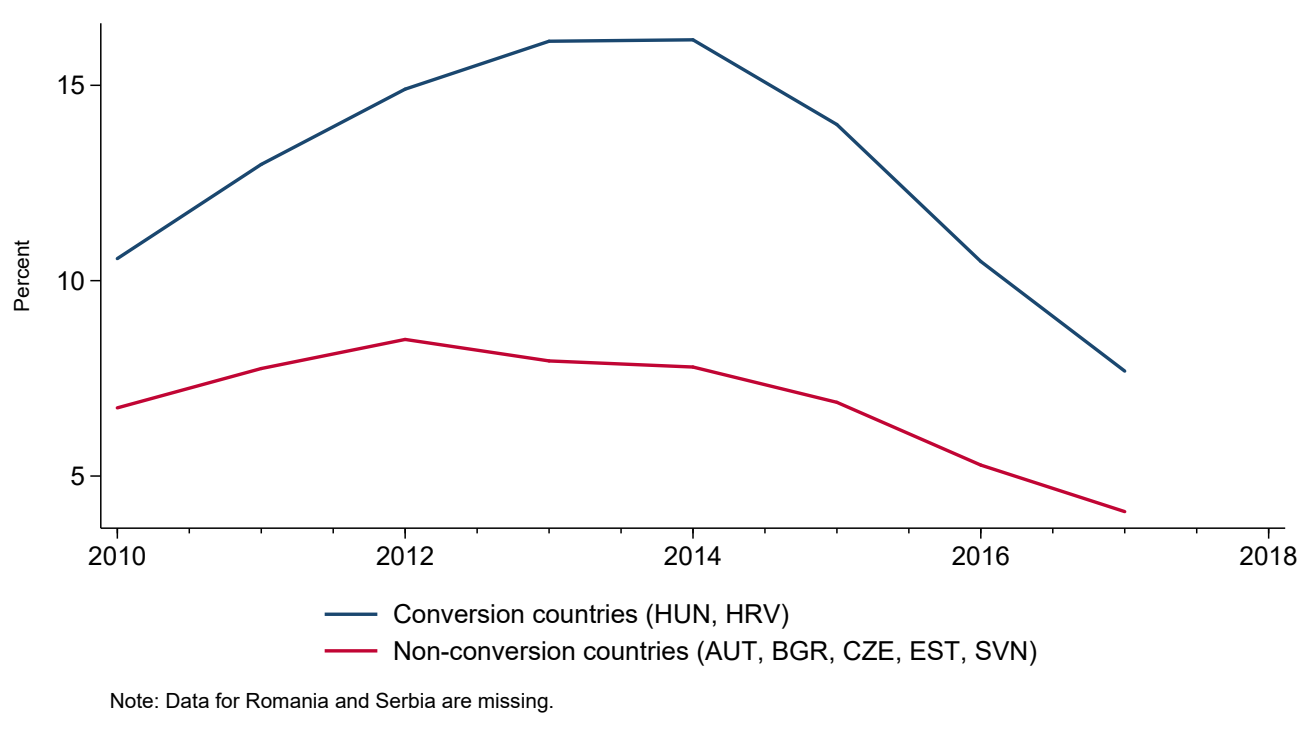

Source: World Bank World Development Indicators and authors' calculations

the sharp decline in loan volumes in the loan conversion countries at the end of the sample. The $77.2 \%$ reduction in the Swiss franc loan volume in Hungary between 2014:Q4 and 2015:Q1 matches well with the timing of the conversion program. The declines in the loan volumes in Croatia (i.e., 1.5\% after 2015:Q3 and 16.2\% after 2015:Q4) and in Romania (i.e., 21.4\% after 2015:Q2, followed by 16.9\% after 2015:Q3) also coincide largely with their respective loan conversion programs, though the drop is less acute than in the Hungarian case.

Two types of loan conversions for Swiss francs were introduced in CEE: governmentsponsored loan conversions (i.e., Hungary and Croatia), and private-sector conversions (i.e., Romania). The two programs differed considerably in the costloans, committed itself to a private sector conversion program in August 2016. Details of the program and its timeline are still to be determined. As of 2018:Q4, Swiss franc loan volumes in Poland had not shown any indication of loan conversions. The Polish case, along with the smaller conversions in Cyprus, Montenegro, and Serbia are not considered in this study due to the lack of data. 
Figure 4: Total Swiss franc loan volumes in conversion countries

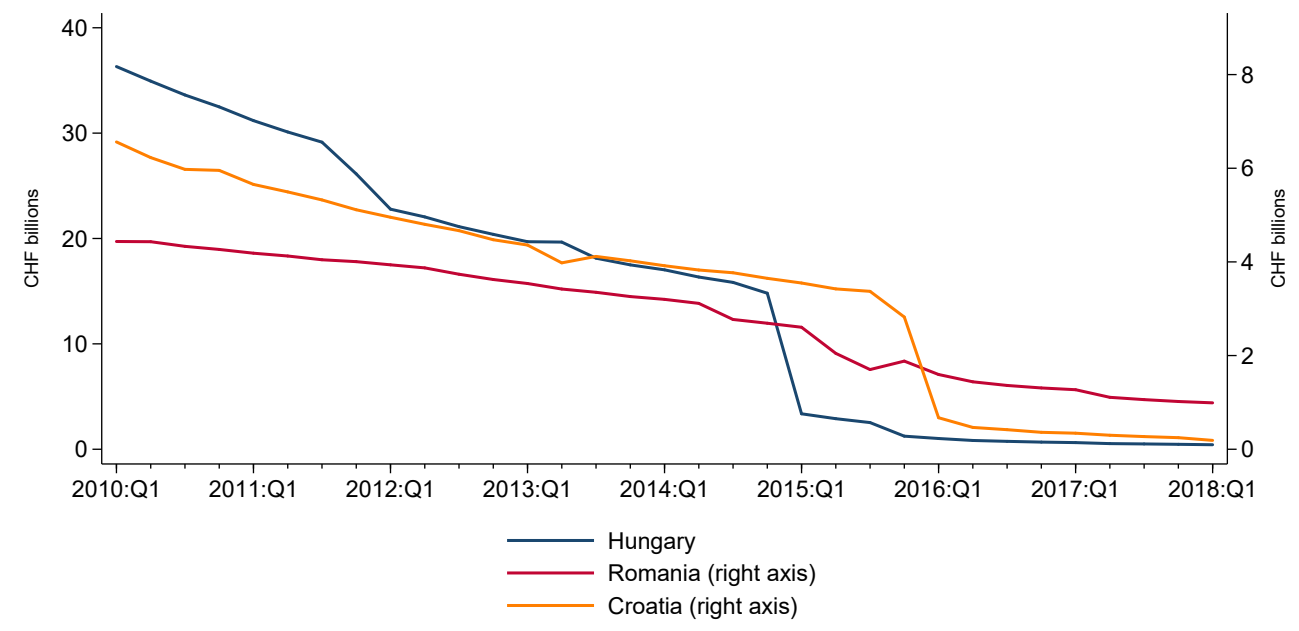

Source: CHF Lending Monitor and authors' calculations

Figure 5: Total Swiss franc loan volumes in non-conversion countries

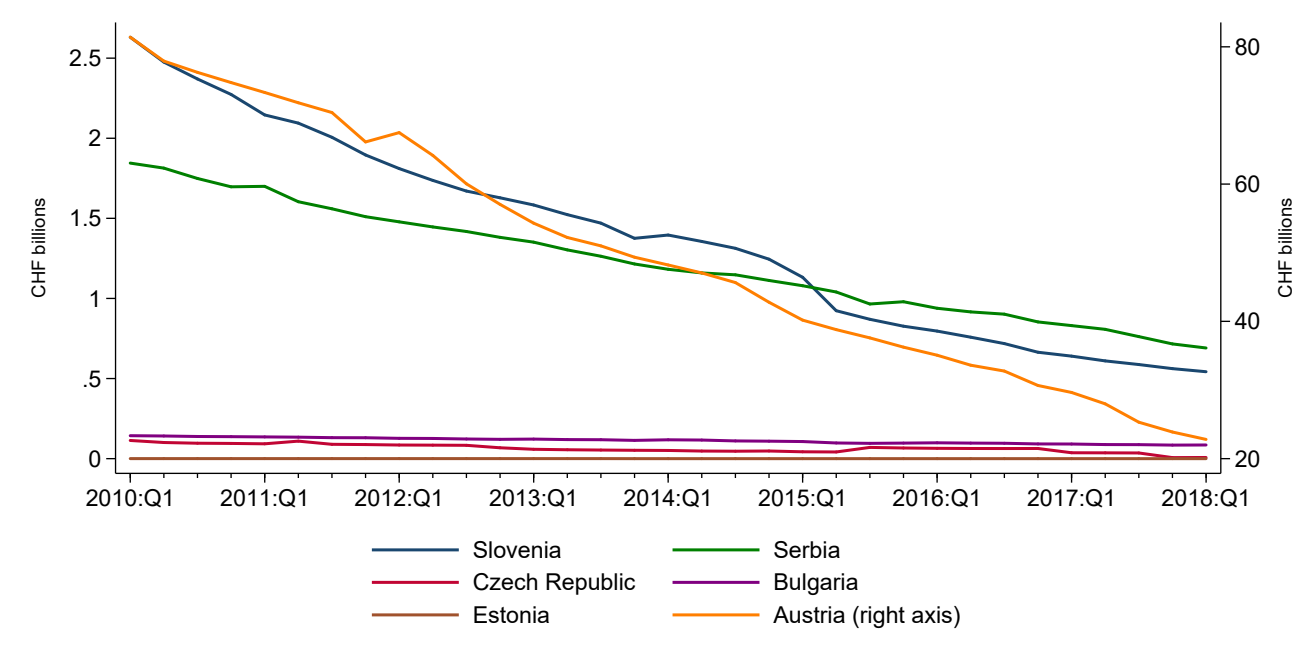

Source: CHF Lending Monitor and authors' calculations 
sharing between lenders and lendees and in the timing of the program's execution. ${ }^{10}$ Government-sponsored conversion programs were backed by legal mandates that dictated the terms for all participants nationwide, whereas the privatesector conversion programs did not operate under any legal decree. The conditions of government-sponsored loan conversions were transparent and publicly communicated. Borrowers had the choice of exercising the conversion option (i.e., converting the loan to a new currency or remaining with the existing Swiss francdenominated loan), but banks had no choice.

The private-sector loan conversion on the other hand was voluntary and allowed banks to dictate the terms and conditions for individual borrowers. These bank-specific conditions were not made public. This difference in legal decree and information also had implications for the level of cost-sharing between banks and borrowers. The costs are believed to have been higher for banks under government-sponsored conversion programs than under private-sector programs. Financial stability concerns and fears that banks would have to bear high costs meant that central banks tended to favor private-sector conversion programs over government-sponsored conversion programs. ${ }^{11}$

The timing is a second difference between the two conversion programs. The government-sponsored conversion programs required all banks to participate at the same time. The private-sector conversion programs instead imposed no predefined timetable. This difference in timing means that the faster adjustment process under the government-sponsored conversion program requires greater coordination. It also imposes greater macroeconomic uncertainty in that the central

\footnotetext{
${ }^{10}$ Beckmann (2017) analyzes with survey data whether households in CEE were aware of debt relief programs (either putative and already implemented). Her analysis, however, does not consider the economic effect of loan conversion programs on banks.

${ }^{11}$ Central banks also argued that foreign banks would leave if the level of the cost burden was too high for them. They also warned that passing laws that intervene in commercial contracts might impact a country's attractiveness for foreign investment and have a negative effect on its risk indicators and credit rating. International credit ratings, however, did not decline in countries when the loan conversion programs were introduced.
} 
bank needs to furnish the necessary foreign reserves before the conversion. Under a private-sector loan conversion program, these adjustment costs are spread over time.

\subsection{Country-specific features of loan conversion programs}

The Hungarian loan conversion from Swiss franc mortgage loans to forint mortgage loans was prepared in November 2014 and was implemented in February 2015. ${ }^{12}$ The conversion affected about 1.3 million households, see ECB (2015c). The exchange rate for the conversion was fixed on November 7, 2014. In light of the SNB actions on January 15, 2015, the timing of the Hungarian conversion was regarded as fortunate for mortgage holders. The volume of Swiss francdenominated loans in Hungary declined sharply from CHF 14.8 billion in 2014:Q4 to CHF 3.8 billion in 2015:Q1 after the conversion.

The Hungarian conversion led to a few changes in the structure of the banking sector's balance sheet. First, so-called "dollarization", or in this case "Swiss francization", decreased significantly in Hungary (i.e., the prevalence of Swiss franc assets in the banking sector's balance sheet). The share of Swiss franc assets to total assets declined from 13\% in 2014:Q4 to 3.9\% in 2015:Q1. Similarly, the share of Swiss franc liabilities to total assets declined from 6\% in 2014:Q4 to 3\% in 2015:Q1. A second feature is that the reliance on wholesale funding to refinance Swiss franc loans decreased significantly after the loan conversion.

The Croatian law on the conversion program did not exactly follow the Hungarian conversion program. The Croatian program facilitated the conversion of loans denominated in Swiss francs into loans denominated in euros or in Croatian kuna that contained a currency clause linking payments to euros; see ECB

\footnotetext{
${ }^{12}$ See Kolozsi et al. (2015) for an in-depth discussion of the events of the Hungarian conversion program. Starting in August 2015, remaining consumer loans denominated in Swiss franc were also phased out.
} 
(2015a). This law, which came into effect on September 30, 2015, placed borrowers of Swiss franc loans in the same position that they would have been in, had their loans been denominated in euros from the very beginning (or denominated in kuna with currency clauses linking payments to euros). This means the original principal amount of the Swiss franc loans was converted to euros (or loans denominated in kuna which contained a currency clause linking payments to euros) at the exchange rate applicable on the date that the Swiss franc loans were made to borrowers. This exchange rate was equal to the exchange rate that the lender applied at that date to loans of the same type and duration, denominated in euros or linked to them. Within 45 days of the date that the draft law entered into force, lenders were required to deliver to borrowers, by registered mail, the calculation of loans thus converted, together with a proposal for a new loan agreement. Borrowers had the option of accepting the conversion within 30 days of receipt of such notification. About $40 \%$ of mortgages in Croatia were denominated in Swiss francs at that time, affecting about 55,000 households. ${ }^{13}$

When introducing measures in relation to settling and converting foreign currency loans, the ECB (2015a and 2015b) has expressed the opinion that "consideration should always be given to fair burden-sharing among all stakeholders, thus also avoiding moral hazard in the future." The Croatian law was retroactive and shifted the costs from households to banks. This, in turn, may also have a negative impact on the profitability, capitalization, and future lending capacity of the affected credit institutions. The ECB's (2015a) assessment suggests that the conversion costs for banks could reach around HRK 8 bn or EUR 1.1 bn, imposing losses for the banking sector equaling to around three years of expected profits. The Hungarian conversion program differed from the Croatian program in that a once-off, non-market exchange rate was applied. As such, it may be argued that

\footnotetext{
${ }^{13}$ From 2007 to 2011, some banks also offered voluntary conversions in Croatia; however, households did not make use of them.
} 
the Hungarian program is more neutral, because households and banks share the costs.

Romania's largest banks offered loan conversion proposals to their clients in a non-uniform manner in 2015. For example, Banca Transilvania offered 11,000 households the opportunity to convert their Swiss franc loans into euros or lei in May 2015. Volksbank Romania followed in July 2015, offering 17,000 households the chance to convert their loans into euros or lei. Then, Bancopost offered interest rates of $1.5 \%$ for three years in lei in September 2015. Then in December 2015, Banca Româneascâ offered 10,500 households the opportunity to convert their loans into euros or lei. Similarly, OTP Bank, Raiffeisen Bank, and Piraeus Bank Romania offered their clients loan conversion proposals. It is unclear how many households restructured their loans and in what currency. The fact that the Romanian parliament introduced a new law to convert Swiss franc-denominated loans in October 2016 suggests that the conversion initiative carried out by the private sector was incomplete.

Table A1 in the appendix summarizes the timeline of events.

\section{$3 \quad$ Foreign currency mismatch indexes}

Our approach for calculating a measure of systemic exchange rate risk for the banking sector in CEE economies follows Ranciere et al. (2010a). This systemic risk measure calculates the net unhedged foreign currency liabilities as a percentage of total assets. In other words, the index of the "exchange-rate-induced credit risk" evaluates the currency mismatch on the balance sheets of CEE banking sectors if households (and non-financial corporations) fail to service their foreign currency loans as a result of a sharp depreciation of the domestic currency.

In the existing literature, currency mismatch in a banking sector is usually measured as the net foreign currency liabilities (i.e., the difference between foreign 
currency liabilities and foreign currency assets) as a share of the total assets of the banking sector. However, banks usually match their foreign currency assets and foreign currency liabilities so that their difference would be almost zero (or sometimes, depending on regulation, identical to zero). Furthermore, this simple measure treats all foreign currency assets equally without considering the risks associated with foreign currency loans given to unhedged borrowers.

Ranciere et al. (2010a) calculate the net foreign currency liabilities as a share of total assets, but exclude the "risky" foreign currency assets from the foreign currency assets. The foreign currency mismatch (FCM) index in the banking sector is thus equal to net foreign currency denominated liabilities plus unhedged foreign currency assets (i.e., loans) divided by total assets:

$$
F C M=\frac{\left(F C Y^{\text {liabilities }}-F C Y^{\text {assets }}+F C Y^{\text {loans to resident households }}\right)}{\text { total bank assets }},
$$

where $F C Y$ denotes foreign currency. In other words, the index measures the mismatch between assets and liabilities in foreign currency, when "risky" foreign currency loans would need to be written off, as share of total assets. The index value ranges between -1 and $+1 .{ }^{14}$ The mismatch index should be treated as an upper bounds for the systemic risk, because it assumes that domestic households are unable to service their foreign currency debt in a crisis. ${ }^{15}$

The data used to construct the foreign currency mismatch index are take from the CHF Lending Monitor, which is an ongoing project of the Swiss National Bank in collaboration with nineteen European central banks, with the aim of understanding the scope of Swiss franc lending in Europe. ${ }^{16}$ The CHF Lending

\footnotetext{
${ }^{14}$ For a more intuitive interpretation, we multiply the index by 100 and refer to it as percent of total assets in the following figures, tables, and empirical analysis.

${ }^{15}$ Our definition of the foreign currency mismatch index treats other unhedged loans to nonfinancial firms as being non-risky. This assumption does not alter the degree of Swiss franc mismatch, because Swiss franc loans are primarily taken by households. This is not the case for other foreign currencies.

${ }^{16}$ The data are confidential and have not been published until now. They have, however, been
} 
Monitor data are quarterly and start as early as 2006 for some countries. The data consist of aggregate banking sector statistics on both the assets and the liabilities sides. More importantly, a currency breakdown between domestic currency, Swiss franc, and other foreign currency is available for all variables in the database. Statistics on total assets and their components, loans and other assets, as well as total liabilities and their components, deposits, own securities issued, and other liabilities are included in the database. Furthermore, a sectoral breakdown of loan and deposit data is available for the following categories: resident banks, resident households, resident nonfinancial corporations, resident government, non-resident banks, and non-resident non-banks. The data template filled out by central banks is illustrated in Figure A1 in the appendix.

With this detailed breakdown, the FCM index can be calculated separately for the Swiss franc and "other foreign currencies", which are believed to be mostly euros in the non-euro area countries. ${ }^{17}$ Countries for which the Swiss franc and "other foreign currency" mismatch indexes can be calculated define our sample: Croatia, Hungary, and Romania as conversion countries; Austria, Bulgaria, Czech Republic, Estonia, Serbia, and Slovenia as non-conversion countries; and Germany, Greece, Italy, Luxembourg, and the UK as our control group. ${ }^{18}$

The FCM index captures only how the banking sector's assets and liabilities would be affected by future exchange rate developments when unhedged borrowers can no longer service their foreign currency debt. This means that the index measures the aggregate risk exposure of the banking sector to a common market shock, e.g., the simultaneous default of unhedged borrowers after a sharp exchange rate movement.

The FCM index is silent on several issues. For example, the index offers a

\footnotetext{
used by Yeşin (2013) and Krogstrup and Tille (2018).

${ }^{17}$ For the Hungarian case, Kolozsi et al. (2015) show that other foreign currency loans are almost exclusively euro loans.

${ }^{18}$ See also Table A2 in the appendix.
} 
macroeconomic perspective and cannot distinguish between banks with different characteristics such as different currency structures and borrower profiles on their balance sheets. Neither can the index give information regarding the banking sector's off-balance-sheet positions which may be partly offsetting on-balance-sheet currency mismatches. Furthermore, contagion by way of the interbank market or information spillovers among banks cannot be captured by this index. It also focuses only on risks that pertain to the banking sector and cannot say anything about households' wealth or nonfinancial corporations' profitability. And, lastly, the index cannot capture potential conversion costs (i.e., future profitability, offbalance-sheet risks, non-performing loans, or maturity mismatches) that may be passed on to banks, for example, through non-market exchange rates. With these constraints, the index is used to assess the evolution of the aggregate risk exposure of banking systems in the CEE region after the implementation of loan conversion programs.

Figure 6 shows the aggregate Swiss franc and the "other foreign currency" mismatch indexes (weighted by currency loan volume) for three CEE countries with a Swiss franc loan conversion program (Croatia, Hungary, and Romania) versus the six CEE countries without a loan conversion program (Austria, Bulgaria, Czech Republic, Estonia, Serbia, and Slovenia). This figure shows that the level of aggregate Swiss franc mismatch for CEE countries with loan conversion programs is low (i.e., below $3 \%$ of total loans) throughout the quarterly sample from 2010 to 2018. The index's decline at the beginning of 2015 is primarily driven by the Hungarian conversion program and coincides with the SNB's discontinuation of its minimum exchange rate policy. The aggregate index for the Swiss franc mismatches for the CEE countries without a loan conversion program is close to zero and rises slightly after the SNB discontinues its minimum exchange rate policy.

The profile of the "other foreign currency" mismatch indexes, shown in Figure 7, differs from the Swiss franc mismatch indexes in several respects. First, the 
Figure 6: CHF mismatch index, weighted by country volumes of Swiss franc loans

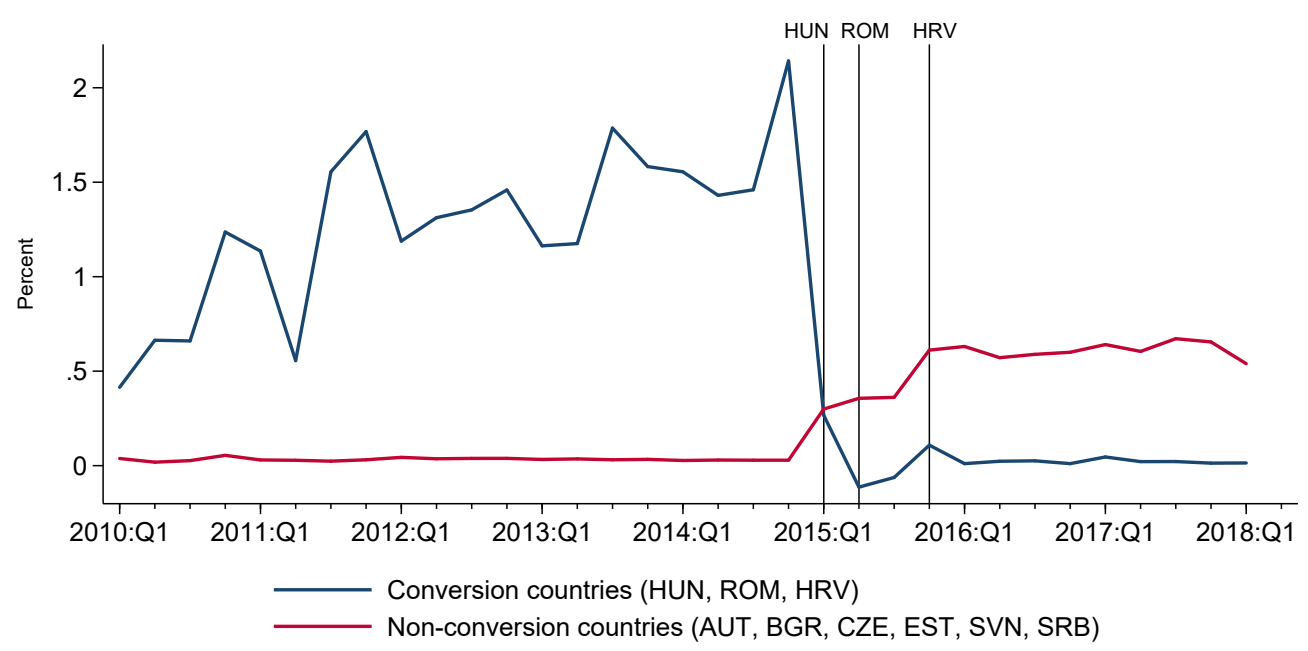

Note: The vertical lines indicate the start of the loan conversion programs.

Source: CHF Lending Monitor and authors' calculations

"other foreign currency" mismatch index is always higher than the corresponding Swiss franc mismatch index. Second, the dynamics of the "other foreign currency" mismatch indexes do not move in parallel with the Swiss franc mismatch indexes. The "other foreign currency" mismatch index declined from 2010 to 2012 and was relatively flat thereafter in both conversion and non-conversion countries. The rapid undoing of Swiss franc loans through loan conversion programs does not appear to influence the "other foreign currency" mismatch index in conversion countries.

Table 1 offers country-level statistics for the two FCM indexes. In each case, except for Slovenia, the mean of the Swiss franc mismatch index is lower than the mean of the "other foreign currency" mismatch index. This suggests that a currency mismatch for euros was most likely a problem for banks in non-euro area countries prior to the loan conversions. Furthermore, high Swiss franc mismatches 
Figure 7: Other foreign currency mismatch index, weighted by country volumes of other foreign currency loans

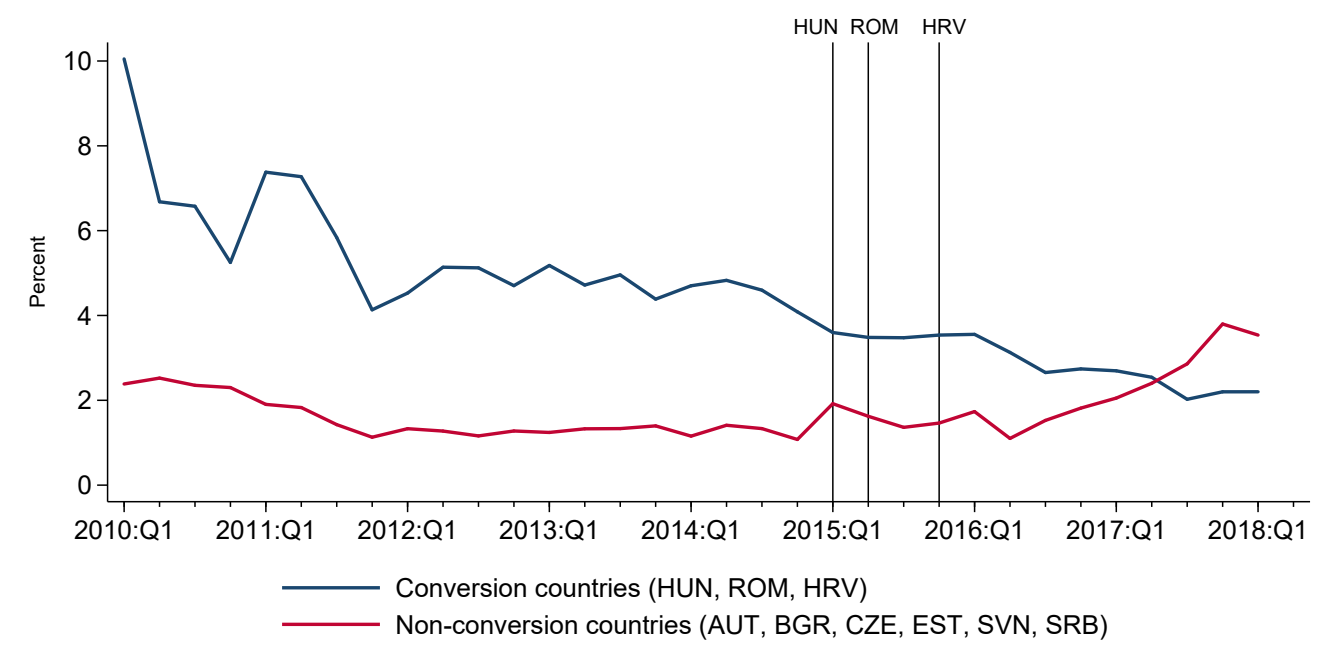

Note: The vertical lines indicate the start of the loan conversion programs.

Source: CHF Lending Monitor and authors' calculations

coincide with high "other foreign currency" mismatches in Croatia and Romania. This suggests that the banking systems of these two countries may suffer from dual currency mismatches.

Table 2 lists the levels of mismatch indexes for the conversion countries Hungary, Croatia, and Romania, immediately before and after the conversions. In all three countries, CHF mismatch indexes decline significantly after the conversions. Yet the decline is more pronounced in Hungary than in the other two countries. Interestingly, the other foreign currency mismatch index increases slightly in all three countries after the conversion programs. 
Table 1: Summary statistics for the currency mismatch indexes

\begin{tabular}{lccc|ccc}
\hline \hline & \multicolumn{3}{c}{ CHF mismatch index } & \multicolumn{3}{c}{ OTH mismatch index } \\
& mean & median & variance & mean & median & variance \\
\hline Austria & -0.11 & -0.06 & 0.03 & 0.75 & 0.78 & 0.15 \\
Bulgaria & 0.04 & 0.04 & 0.00 & -6.34 & -6.39 & 3.01 \\
Croatia & 2.18 & 3.04 & 2.62 & 13.66 & 13.65 & 1.16 \\
Czech Republic & 0.01 & 0.01 & 0.00 & 2.29 & 2.44 & 5.71 \\
Estonia & 0.02 & 0.01 & 0.00 & 2.89 & 2.83 & 2.47 \\
Germany & -0.27 & -0.27 & 0.01 & 0.80 & 0.77 & 0.15 \\
Greece & -0.82 & -0.85 & 0.01 & -1.90 & -1.73 & 0.39 \\
Hungary & 0.52 & -0.01 & 0.87 & 3.45 & 4.94 & 8.39 \\
Italy & 0.01 & 0.01 & 0.00 & -0.36 & -0.28 & 0.04 \\
Luxembourg & -0.45 & -0.59 & 0.84 & 1.52 & 1.94 & 6.04 \\
Romania & 1.26 & 1.27 & 0.27 & 8.57 & 8.53 & 1.90 \\
Serbia & 1.04 & 1.03 & 0.01 & 3.53 & 3.40 & 1.22 \\
Slovenia & 0.94 & 0.98 & 0.09 & -0.54 & -0.56 & 0.01 \\
United Kingdom & -0.10 & -0.10 & 0.01 & 0.09 & 0.28 & 0.70 \\
\hline \hline
\end{tabular}

Note: The sample is from 2013:Q1 to 2017:Q4. The definition of the CHF and OTH (other foreign currency) mismatch indexes is given in equation (1).

Source: CHF Lending Monitor and authors' calculations. 
Table 2: Mismatch indexes before and after the conversion programs

\begin{tabular}{l|cc|cc}
\hline \hline & \multicolumn{2}{|c}{ before conversion } & \multicolumn{2}{c}{ after conversion } \\
& $\begin{array}{c}\text { CHF mismatch } \\
\text { index }\end{array}$ & $\begin{array}{c}\text { OTH mismatch } \\
\text { index }\end{array}$ & $\begin{array}{c}\text { CHF mismatch } \\
\text { index }\end{array}$ & $\begin{array}{c}\text { OTH mismatch } \\
\text { index }\end{array}$ \\
\hline \multirow{2}{*}{ Hungary } & Q4 2014 & Q4 2014 & Q1 2015 & Q1 2015 \\
& 2.221 & 4.797 & 0.018 & 6.111 \\
\hline \multirow{2}{*}{ Croatia } & Q4 2015 & Q4 2015 & Q1 2016 & Q1 2016 \\
& 0.841 & 14.787 & 0.430 & 15.736 \\
\hline \multirow{2}{*}{ Romania } & Q1 2015 & Q1 2015 & Q2 2015 & Q2 2015 \\
& 1.619 & 9.264 & 1.375 & 10.198 \\
\hline \hline
\end{tabular}

Note: The definition of the CHF and OTH (other foreign currency) mismatch indexes is given in equation (1).

Source: CHF Lending Monitor and authors' calculations.

\section{Econometric specification}

The effect of loan conversion programs on foreign currency mismatch indexes is estimated with the following specification:

$$
F C M_{i j t}=\beta C H F_{j} L C P_{i t}+\gamma X_{i t}+\delta C H F_{j} X_{i t}+\mu_{i}+\lambda_{t}+\varepsilon_{i j t},
$$

where $F C M_{i j t}$ is the level of the foreign currency mismatch index for country, $i$, currency, $j$ (i.e., Swiss franc or "other foreign currency"), and time, $t$. The binary variable, $L C P_{i t}$, captures the effect of the loan conversion program and is 1 for periods when the loan conversion program was first active in country $i$ to the end of the sample and is 0 otherwise. $L C P_{i t}$ captures three conversion programs with the following start dates: Hungary in 2014:Q4, Croatia in 2015:Q3, and Romania in 2015:Q2. The "Swiss franc" variable, $C H F_{j}$, is 1 when $j=$ Swiss franc currency and 0 when $j=$ other currency. This variable is interacted with the loan conversion variable, $L C P_{i t}$, to filter out the effect for the "Swiss franc currency" mismatch. 
The coefficient of the interaction term, $C H F_{j}{ }^{*} L C P_{i t}$, captures the direct channel, which arises from the conversion program from Swiss francs to another currency.

Equation (2) also includes control variables, $X_{i t}$, for country, $i$. The control variables are also interacted with $C H F_{j}$ to separate their effects for the individual currency mismatches. The control variables are currency cross rates (i.e., eurodomestic currency and Swiss franc-domestic currency), two measures of risk (i.e., VIX and CDS spreads), indicators for macroprudential measures, non-performing loans, and stock market performance, as well as interest rate differentials. ${ }^{19}$ The binary variables, $C H F_{j}$ and $L C P_{i t}$, do not enter separately, because of the country fixed effects, $\mu_{i}$, and the quarterly time effects, $\lambda_{t}$. The residual of the foreign currency mismatch index for country, $i$, currency, $j$, and time, $t$ is denoted by $\varepsilon_{i j t}$.

The empirical analysis seeks to uncover the separate effects of Swiss franc loan conversion programs on the Swiss franc and the "other foreign currency" mismatch indexes. A key assumption is that CEE banks suffer from dual currency mismatches. Two hypotheses are considered. First, loan conversion programs reduce currency mismatches for the Swiss franc index, i.e., $\beta<0$. Second, loan conversion programs increase currency mismatches for the "other currency" index. In this second hypothesis, loan conversion programs that convert Swiss franc mortgage loans into euro mortgage loans (i.e., in Croatia and, partially, Romania) lead to a deterioration in the "other foreign currency" mismatch index. For this second hypothesis, the binary variable, $O T H_{j}$, which replaces the $C H F_{j}$ variable in equation (2), is 1 when $j=$ other foreign currency and 0 when $j=$ Swiss franc currency. The interaction of this variable with $L C P_{i t}$ will capture the effect of loan programs on other foreign currency mismatch indexes, as illustrated in equation (3) below.

\footnotetext{
${ }^{19}$ Table A3 in the appendix offers a short description and sources of the control variables in equation (2).
} 


$$
F C M_{i j t}=\beta O T H_{j} L C P_{i t}+\gamma X_{i t}+\delta O T H_{j} X_{i t}+\mu_{i}+\lambda_{t}+\varepsilon_{i j t},
$$

The empirical strategy also allows for differences in cross-country experiences due to specifics of each individual program. Therefore, the impact of individual loan conversion programs on the CHF mismatch index is estimated separately using the specifications shown below.

$$
\begin{aligned}
& F C M_{i j t}=\beta C H F_{j} H U N L C P_{t}+\gamma X_{i t}+\delta C H F_{j} H U N L C P_{t} X_{i t}+\mu_{i}+\lambda_{t}+\varepsilon_{i j t} \\
& F C M_{i j t}=\beta C H F_{j} H R V L C P_{t}+\gamma X_{i t}+\delta C H F_{j} H R V L C P_{t} X_{i t}+\mu_{i}+\lambda_{t}+\varepsilon_{i j t} \\
& F C M_{i j t}=\beta C H F_{j} R O M L C P_{t}+\gamma X_{i t}+\delta C H F_{j} R O M L C P_{t} X_{i t}+\mu_{i}+\lambda_{t}+\varepsilon_{i j t}
\end{aligned}
$$

In a similar manner, the impact of the conversion programs on the OTH mismatch index is estimated separately for Hungary, Croatia, and Romania.

\section{Estimation results}

This section presents estimation results based on equations (2)-(6) for a balanced panel between 2013:Q1 and 2017:Q4. The country samples are given in Table A2 in the appendix, and the variable definitions and sources are listed in Table A3 and Table A4 in the appendix. All regressions include country fixed effects and time effects. Standard errors are robust standard errors. ${ }^{20}$

The empirical results support three findings: each suggests that the specifics of loan conversion programs are important. First, the timing of the execution of the conversion programs coincided with a strong reduction in the CHF mismatch index in all three countries. On average, the loan conversion programs reduced the

\footnotetext{
${ }^{20}$ The structure of the dataset is not conducive to clustering by country. Although the low number of country groups could be overcome by the clustering method proposed by Cameron et al. 2008, the low number of observations within groups ( 2 in our case) remains problematic.
} 
CHF currency mismatch index by 2 percentage points. It must be remembered from Figure 5 that the $\mathrm{CHF}$ mismatch indexes did not demonstrate large imbalances and that the 2 percentage point improvement represents a near-balanced position after the loan conversions were implemented. Second, the same conversion programs did not have a uniform impact on other foreign currency mismatch indexes. The direction of the program's effect depends on whether the conversion was from Swiss francs to domestic currency or to euro. In the latter case, the loan conversion program increased the risks of the other currency mismatch index for Croatia. In the former case, the loan conversion program decreased the risks of the other currency mismatch index for Hungary. Third, the strongest effects of a loan conversion program on the currency mismatch index are always for government-sponsored loan conversion programs. This is explained by the fact that all stakeholders were forced to participate by a specified date.

Table 3 presents regressions that show the effect of loan conversion programs on the CHF mismatch index. The coefficient of interest ranges between -1.8 and -2.7 , depending on the specification, and is always statistically significant at conventional significance levels. The first column documents the combined effect of the loan conversion programs in Hungary, Croatia, and Romania on the CHF mismatch index for a sample of nine CEE countries. This combined effect leads to a reduction of 1.9 percentage points in the CHF mismatch index. The same regression for a larger sample that includes five European countries with a considerable share of Swiss franc loans (the United Kingdom, Germany, Greece, Italy, and Luxembourg) is presented in column 2. Again, the effect of the loan conversion programs reduces the CHF mismatch index by 1.9 percentage points. Next, columns 3 to 10 show that the effect of the loan conversion programs is robust to the introduction of different control variables in regressions with the smaller sample of nine CEE countries. The control variables include the exchange rate (i.e., the domestic currency versus the CHF and the domestic currency versus the 
euro), an indicator for macroprudential measures, an indicator for non-performing loans, an indicator for the banking sector's stock market performance, an uncertainty measure defined by the VIX, and the interest rate spread. Among the control variables, only the exchange rates are found to be an important factor. There is weak evidence that non-performing loans may also be a decisive control variable.

Table 4 presents evidence that the effect of the loan conversion programs was not similar across individual countries. Three panels of regressions show the coefficient from the individual loan conversion programs on the CHF mismatch index. The format of Table 4 follows the regressions presented in Table 3. Panel (i) shows that the interaction of $C H F_{j}$ with the timing of the Hungarian loan conversion program, $H U N L C P_{t}$, is -1.6 and statistically significant in columns 1 and 2. This coefficient ranges between -0.9 and -1.9 depending on the specification, though, it is always statistically significant except when non-performing loans are considered as a control in column 6. Next, panel (ii) shows the same interaction between the $C H F_{t}$ dummy and the timing of the loan conversion program for Croatia, $H R V L C P_{t}$. Here, the evidence is stronger than in the Hungarian case. The effect of the Croatian loan conversion program appears stable in all specifications. The coefficient estimates range between -2.8 and -3.3 and are highly statistically significant. Finally, panel (iii) shows regressions for the Romanian loan conversion program. Here, the country-level evidence is the weakest. In most cases, the effect of the Romanian loan conversion effect was close to zero and statistically insignificant. 


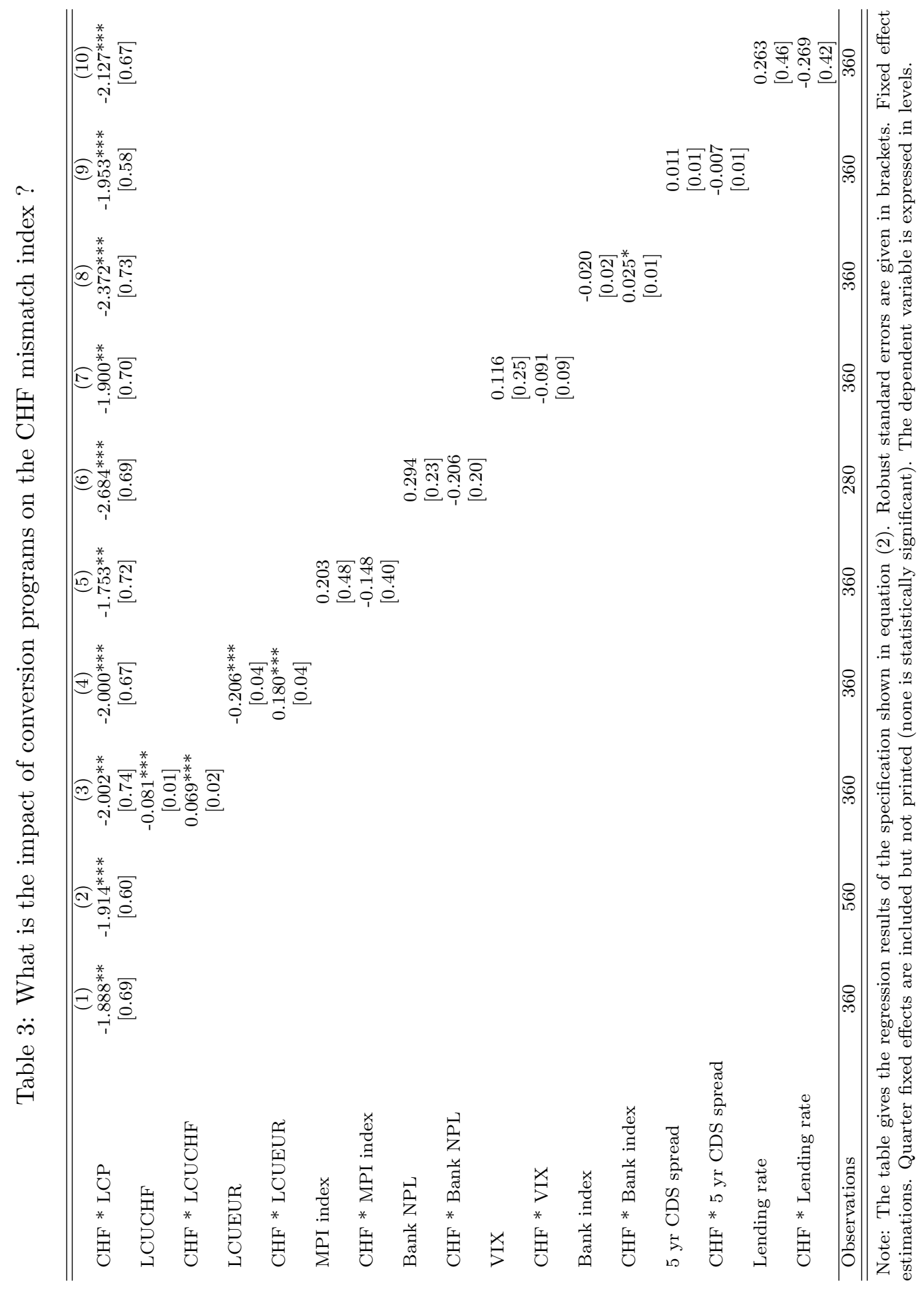




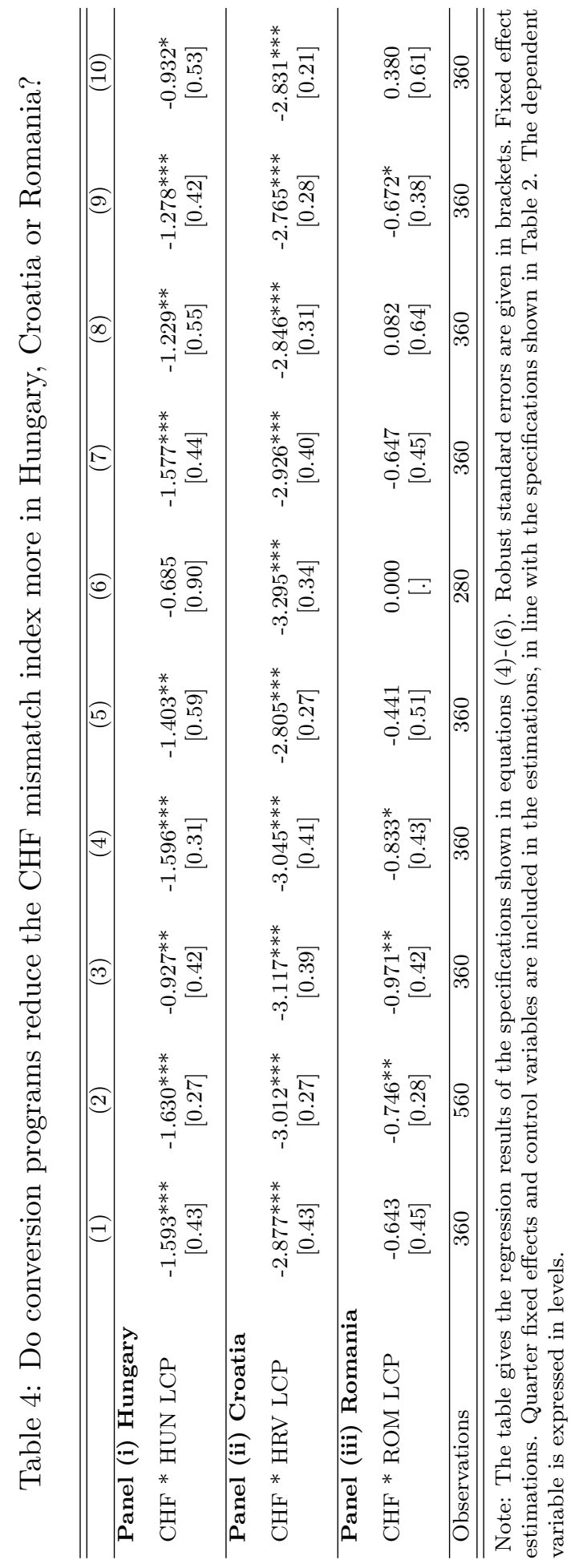


A further important consideration is whether loan conversion programs affect currency mismatches in other foreign currencies. Because the Croatian and, partially, the Romanian programs converted Swiss francs loans into euro-denominated loans, it is unclear whether the loan conversion programs in these two countries resulted in a deterioration in the other foreign currency mismatch index. To analyze for possible offsetting effects in another foreign currency, the next two tables present evidence on the effects of loan conversion programs on the other foreign currency mismatch index.

Table 5 presents evidence for the combined effect of loan conversion programs in Hungary, Croatia, and Romania on the other currency mismatch index. The format of Table 5 for the other currency mismatch index follows the same presentation of the regressions in Table 3 for the CHF mismatch index. The results show that the coefficient of interest is negative and statistically insignificant. This result suggests that the loan conversion programs are on average neutral towards other currency mismatches. However, a closer examination of the individual loan conversion programs reveals that the specifics of each individual program are important.

Table 6 follows Table 4 in presenting regression evidence for the effect of individual loan conversion programs on the other currency mismatch index. Panel (i) shows the regressions for the Hungarian case. The effect of the loan conversion program is negative and highly statistically significant. The evidence in column 1 suggests that the loan conversion program resulted in a 3.8 percentage point reduction in the other currency mismatch index, which was a stronger effect than in the case of the CHF mismatch index. The result of these reductions in both mismatch indexes is somewhat surprising, because the Hungarian program was specific in converting Swiss franc-denominated loans into domestic currency. A possible explanation, although we are unable to provide empirical evidence for it, is that the state-sponsored loan conversion program highlighted the risks of 
foreign currency loans in general, and as a consequence there was also a strong reduction in the demand for short-term euro-denominated loans.

Next, panel (ii) shows that the effect of the Croatian loan conversion program resulted in a strong increase in the other currency mismatch index. This result is consistent with the state-sponsored program's intention to convert Swiss franc loans to euro loans. The coefficient estimates are positive and statistically significant. The coefficient estimate in column 1 says that the Croatian loan conversion program increased the other currency mismatch index by 1.5 percentage points. This result is important because the imbalances for the other currency mismatch index are substantially higher than for the CHF mismatch index.

Finally, panel (iii) shows that the effect of the Romanian loan conversion program resulted in a weak increase in the other currency mismatch index. The coefficient estimates are close to zero and are statistically insignificant. These weaker results are consistent with the view that the loan conversion program from Swiss franc-denominated loans to euro denominated loans was only partial. Furthermore, the evidence suggests that the state-sponsored programs had a stronger effect in eliminating currency risk for the banking sector than did the private-sector sponsored programs. 


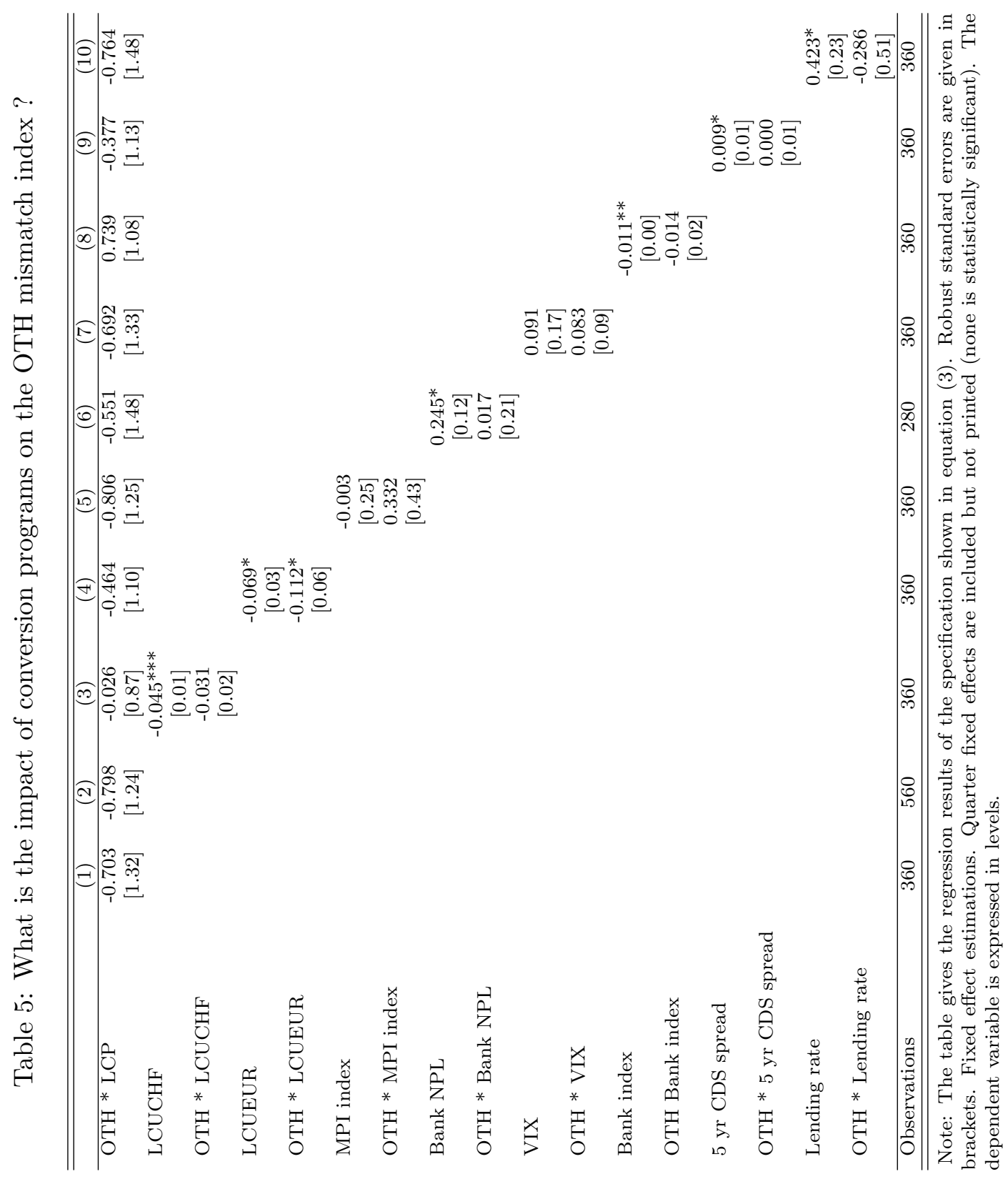




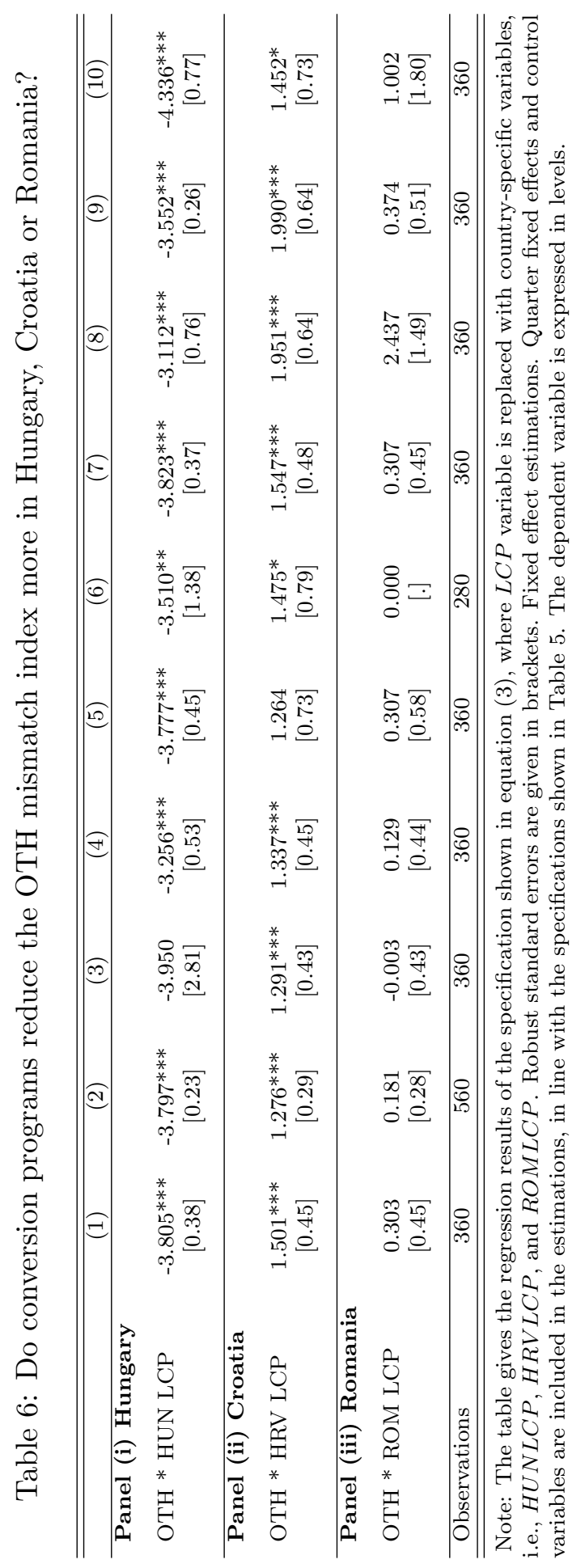




\section{Conclusions}

This paper is the first to consider the effect of foreign currency loan conversion programs as a preventive macroprudential policy measure to reduce systemic exchange rate risks to bank balance sheets. Our empirical findings support the view that loan conversion programs were successful in reducing Swiss franc exposure in CEE banking systems. However, these programs also heightened the exchange rate risks in other foreign currencies in individual countries. This latter result for the other foreign currency mismatch indexes suggests that Swiss franc loan conversions into euros (rather than into domestic currency) are only marginally able to reduce aggregate systemic exchange rate risks to bank balance sheets. Euro mismatches remain a considerable risk to financial stability for countries that implemented loan conversion programs. 


\section{References}

Acosta-Ormaechea, S. and Coble, D. O., 2011. Monetary transmission in dollarized and non-dollarized economies; The cases of Chile, New Zealand, Peru and Uruguay, IMF Working Paper, No.11/87, International Monetary Fund.

Albacete, N. and Lindner, P., 2015. Foreign currency borrowers in Austria evidence from the Household Finance and Consumption Survey, Financial Stability Report, Austrian Central Bank, 29, 93-109.

Andrieş, A. M., Fischer, A. M. and Yeşin, P., 2017. The asymmetric impact of international swap lines on banks in emerging markets, Journal of Banking and Finance, 75(C), 215-234.

Andrieş, A. M. and Nistor, S., 2018. Systemic risk and foreign currency positions of banks: Evidence from Emerging Europe, Eastern European Economics, $56(5), 382-421$.

Auer, R., Burstein, A. and Lein, S. M., 2018. Exchange rates and prices: evidence from the 2015 Swiss franc appreciation, BIS Working Papers, No. 751, Bank for International Settlements.

Auer, R. A., Kraenzlin, S. and Liebeg, D., 2012. How do Austrian banks fund their Swiss franc exposure?, OeNB Financial Stability Report 24 (December), 54-61.

Banerjee, R., Devereaux, M. B. and Lombardo, G., 2016. Self-oriented monetary policy, global financial markets and excess volatility of international capital flows, Journal of International Money and Finance, 68, 275-297.

Beckmann, E., 2017. How does foreign currency debt relief affect households' loan demand? Evidence from the OeNB Euro Survey in CESEE, Focus on European Economic Integration, Austrian Central Bank, Q1/17, 8-32.

Beckmann, E. and Stix, H., 2015. Foreign currency borrowing and knowledge about exchange rate risk, Journal of Economic Behavior and Organization, $112(\mathrm{C}), 1-16$.

Beer, C., Ongena, S. and Peter, M., 2010. Borrowing in foreign currency: Austrian households as carry traders, Journal of Banking and Finance, 34(9), 2198-2211.

Bernanke, B. S., 2015. Federal Reserve policy in an international context, MundellFleming Lecture at the $16^{\text {th }}$ Jacques Polak Annual Research Conference, November 2015, International Monetary Fund, Washington, D.C. 
Bonadio, B., Fischer, A.M. and Sauré, P., 2019. The speed of exchange rate pass-through, Journal of the European Economic Association, forthcoming.

Brown, M. and De Haas, R., 2012. Foreign banks and foreign currency lending in emerging Europe, Economic Policy, 27(69), 57-98.

Brown, M., Ongena, S., and Yeşin, P., 2011. Foreign currency borrowing by small firms in the transition economies, Journal of Financial Intermediation, 20(3), 285-302.

Brown, M., Ongena, S. and Yeşin, P., 2014. Information asymmetry and foreign currency borrowing by small firms, Comparative Economic Studies, 56(1), 110-131.

Cameron, A. C., Gelbach, J. B. and Miller, D. L., 2008. Bootstrap-based improvements for inference with clustered errors, Review of Economics and Statistics 90(3), 414-427.

Canova, F., 2005. The transmission of US shocks to Latin America, Journal of Applied Econometrics, 20(2), 229-251.

Catão, L. and Terrones, M., 2016. Financial de-dollarization; A global perspective and the Peruvian experience, IMF Working Paper, No. 16/97, International Monetary Fund.

Cerutti, E. M., Claessens, S. and Laeven, L., 2017. The use and effectiveness of macroprudential policies: New evidence, Journal of Financial Stability, 28, 203-224.

Cerutti, E. M., Correa, R., Fiorentino, E. and Segalla, E., 2016. Changes in prudential policy instruments: A new cross-country database, IMF Working Paper, No. 16/110, International Monetary Fund.

De Nicolò G. and Lucchetta, M., 2009. Financial intermediation, competition, and risk: a general equilibrium exposition, IMF Working Paper, No. 09/105, International Monetary Fund.

Di Giovanni, J. and Shambaugh, J. C., 2008. The impact of foreign interest rates on the economy: The role of the exchange rate regime, Journal of International Economics, 74(2), 341-361.

European Central Bank, 2014. Financial Stability Review, May 2014. 
European Central Bank, 2015a. Opinion on the conversion of Swiss franc loans $(\mathrm{CON} / 2015 / 32)$, Croatia, 18.9.2015.

European Central Bank, 2015b. Opinion on a draft law on specific terms of restructuring of home loans denominated in foreign currency $(\mathrm{CON} / 2015 / 26)$, Poland.

European Central Bank, 2015c. Opinion on the conversion of foreign exchange loans (CON/2014/87), Hungary, 16.12.2014.

Fidrmuc, J., Hake, M. and Stix, H. 2013. Households' foreign currency borrowing in Central and Eastern Europe, Journal of Banking and Finance, 37, 18801897.

Fischer, A. M. and Yeşin, P., 2016. Undoing CHF mortgage loans in post-crisis Eastern Europe, mimeo, Swiss National Bank.

Galindo, A. and Leiderman, L., 2005. Living with dollarization and the route to dedollarization, Inter-American Development Bank, Working Paper, No. 526.

Georgiadis, G., 2016. Determinants of global spillovers from US monetary policy, Journal of International Money and Finance, 67(C), 41-61.

Gopinath, G. and Stein J.C., 2018. Banking, trade, and the making of a dominant currency, mimeo, Harvard University.

Ize, A. and Levy-Yeyati, E. L., 2003. Financial dollarization, Journal of International Economics, 59(2), 323-347.

Kolozsi, P. P., Banai, A. and Vonnák, B., 2015. Phasing out household foreign currency loans: schedule and framework, Financial and Economic Review, $14(3), 60-87$.

Krogstrup S. and Tille C., 2018. Foreign currency bank funding and global factors, CEPR Discussion Paper, No. 12933, Centre for Economic Policy Research.

Luca, A. and Petrova, I., 2008. What drives credit dollarization in transition economies?, Journal of Banking and Finance, 32(5), 858-69.

Miniane, J. and Rogers, J. 2007. Capital controls and the international transmission of U. S. money shocks, Journal of Money, Credit and Banking, 39(5), 1003-1035. 
Qureshi, M. S., Ostry, J. D., Ghosh, A. R. and Chamon, M., 2011. Managing capital inflows: The role of capital controls and prudential policies, NBER Working Paper, No. 17363, National Bureau of Economic Research.

Ranciere, R., Tornell, A. and Vamvakidis, A. 2010a. Currency mismatch, systemic risk and growth in Emerging Europe, Economic Policy, 25(64), 597-658.

Ranciere, R., Tornell, A. and Vamvakidis, A., 2010b. A new index of currency mismatch and systemic risk, IMF Working Paper, No. 10/263, International Monetary Fund.

Reinhart, C. M., Rogoff, K. S. and Savastano, M. A., 2014. Addicted to dollars, Annuals of Economics and Finance, 15(1), 1-51.

Rennhack, R. and Nozaki, M., 2006. Financial dollarization in Latin America, IMF Working Paper, No. 06/7, International Monetary Fund.

Temesvary, J. 2016. The drivers of foreign currency-based banking in Central and Eastern Europe, Economics of Transition, 24(2), 233-257.

Yeşin, P., 2013. Foreign currency loans and systemic risk in Europe, Federal Reserve Bank of St. Louis Review, May/June, 95(3), 219-35. 


\section{Appendix}

Figure A1: Data template filled out by central banks about their respective banking systems

(Volumes in millions of local currency units, end of quarter)

\begin{tabular}{|c|c|c|c|c|}
\hline \multirow[t]{2}{*}{ A. Assets of resident banks ${ }^{1}$} & \multicolumn{3}{|c|}{ Denomination } & \\
\hline & \begin{tabular}{|l} 
Local currency \\
A \\
\end{tabular} & $\begin{array}{l}\mathrm{CHF}^{2} \\
\mathrm{~B}\end{array}$ & $\begin{array}{l}\text { All other currencies }{ }^{3} \\
\text { C }\end{array}$ & $\begin{array}{l}\text { Total } \\
=A+B+C\end{array}$ \\
\hline $\begin{array}{l}\text { 1. Loans to residents }{ }^{4} \\
\text { Banks } \\
\text { Non-banks } \\
\text { of which: to households } \\
\text { of which: to non-financial corporations } \\
\text { of which: to general government (public sector) }\end{array}$ & & & & \\
\hline \multicolumn{5}{|l|}{ 2. Loans to non-residents ${ }^{4}$} \\
\hline \\
\hline \multicolumn{5}{|l|}{ 3. Other assets } \\
\hline \multicolumn{5}{|l|}{ 4. Total assets $(=1 .+2 .+3)}$. \\
\hline \multirow[t]{2}{*}{ B. Liabilities of resident banks ${ }^{1}$} & \multicolumn{3}{|c|}{ Denomination } & \\
\hline & \begin{tabular}{|l} 
Local currency \\
A
\end{tabular} & $\begin{array}{l}\mathrm{CHF}^{2} \\
\mathrm{~B}\end{array}$ & $\begin{array}{l}\text { All other currencies }{ }^{3} \\
\text { C }\end{array}$ & $\begin{array}{l}\text { Total } \\
=A+B+C\end{array}$ \\
\hline $\begin{array}{l}\text { 1. Deposits from residents }{ }^{5} \\
\text { Banks } \\
\text { Non-banks } \\
\text { of which: from households } \\
\text { of which: from non-financial corporations } \\
\text { of which: from general government (public sector) }\end{array}$ & & & & \\
\hline \\
\hline Banks & \multicolumn{4}{|c|}{ 2. Deposits from non-residents ${ }^{5}$} \\
\hline \multirow{2}{*}{\multicolumn{5}{|c|}{$\begin{array}{l}\text { Non-banks } \\
\text { 3. Own securities issued }\end{array}$}} \\
\hline & & & & \\
\hline $\begin{array}{l}\text { 4. Other liabilities }{ }^{7} \\
\text { 5. Total liabilities }(=1 .+2 .+3 .+4 .)\end{array}$ & & & & \\
\hline
\end{tabular}

Notes:

${ }^{1}$ Banks = "other depository corporations" according to IMF Monetary and Financial Statistics Manual, p. 28, or

"other monetary financial institutions" according to ECB definition.

${ }^{2}$ Denominated in, or indexed to, the Swiss franc (CHF).

${ }^{3}$ Denominated in, or indexed to, foreign currencies.

${ }^{4}$ Loans as in ECB Monthly Bulletin, Table 2.1. (Aggregated balance sheet of euro area MFIs).

${ }^{5}$ Deposits as in ECB Monthly Bulletin, Table 2.1. (Aggregated balance sheet of euro area MFIs).

${ }^{6}$ Money market paper, medium-term notes, and long-term bonds.

${ }^{7}$ Including capital and reserves.

Source: SNB's CHF Lending Monitor. 
Table A1: Timeline of events

\begin{tabular}{l|l}
\hline November 2014 & $\begin{array}{l}\text { The Hungarian government adopts legislative } \\
\text { measures to convert foreign exchange and foreign } \\
\text { exchange-based loan contracts into forint }\end{array}$ \\
\hline November 2014 & $\begin{array}{l}\text { The exchange rate for the conversion program in } \\
\text { Hungary is set by the Hungarian Central Bank }\end{array}$ \\
\hline 15 January 2015 & The exchange rate floor is discontinued by the SNB \\
\hline 28 February 2015 & $\begin{array}{l}\text { Swiss franc mortgages are converted into forint in } \\
\text { Hungary }\end{array}$ \\
\hline May 2015 & $\begin{array}{l}\text { Voluntary conversions of Swiss franc loans into either } \\
\text { lei or euros start in Romania }\end{array}$ \\
\hline September 2015 & $\begin{array}{l}\text { The Law on Consumer Credit and Law on Credit } \\
\text { Institutions are signed in Croatia to convert Swiss } \\
\text { franc loans into euros }\end{array}$ \\
\hline March 2016 & $\begin{array}{l}\text { The majority of loan conversions are conducted in } \\
\text { Croatia }\end{array}$ \\
\hline
\end{tabular}

Table A2: List of countries in the sample

\begin{tabular}{|c|c|}
\hline \multicolumn{2}{|c|}{ Baseline sample $=$ conversion countries + non-conversion countries } \\
\hline Conversion countries & $\begin{array}{l}\text { Croatia (HRV), Hungary (HUN), Romania } \\
\text { (ROM) }\end{array}$ \\
\hline Non-conversion countries & $\begin{array}{l}\text { Austria (AUT), Bulgaria (BGR), Czech } \\
\text { Republic (CZE), Estonia (EST), Serbia (SRB), } \\
\text { Slovenia (SVN) }\end{array}$ \\
\hline \multicolumn{2}{|c|}{ Extended sample $=$ baseline sample + control countries } \\
\hline Control countries & $\begin{array}{l}\text { Germany (DEU), Greece (GRC), Italy (ITA), } \\
\text { Luxembourg (LUX), the UK (GBR) }\end{array}$ \\
\hline
\end{tabular}


Table A3: List of control variables in the empirical analysis

\begin{tabular}{|c|c|c|}
\hline Label & Definition & Source \\
\hline$L C U C H F_{i t}$ & Exchange rate local currency per $1 \mathrm{CHF}$ & Reuters \\
\hline$L C U E U R_{i t}$ & Exchange rate local currency per 1 EUR & Reuters \\
\hline$M P I_{i t}$ & Macroprudential index & $\begin{array}{l}2018 \\
\text { update of } \\
\text { Cerutti, } \\
\text { Claessens, } \\
\text { and Laeven } \\
(2017)\end{array}$ \\
\hline$N P L_{i t}$ & $\begin{array}{l}\text { Bank non-performing loans to total gross loans. } \\
\text { Bank non-performing loans to total gross loans } \\
\text { are the value of non-performing loans divided } \\
\text { by the total value of the loan portfolio } \\
\text { (including non-performing loans before the } \\
\text { deduction of specific loan-loss provisions). The } \\
\text { loan amount recorded as non-performing } \\
\text { should be the gross value of the loan as } \\
\text { recorded on the balance sheet, not just the } \\
\text { amount that is overdue. Loans are classified as } \\
\text { non-performing when payments of principal } \\
\text { and interest are } 90 \text { days or more past due or } \\
\text { when future payments are not expected to be } \\
\text { received in full. }\end{array}$ & $\begin{array}{l}\text { World } \\
\text { Bank } \\
\text { World De- } \\
\text { velopment } \\
\text { Indicators } \\
\text { (data } \\
\text { missing for } \\
\text { Romania } \\
\text { and Serbia) }\end{array}$ \\
\hline$V I X_{t}$ & $\begin{array}{l}\text { Chicago Board Options Exchange volatility } \\
\text { index }\end{array}$ & Datastream \\
\hline Bank $_{i t}$ & Bank equity indexes for country $i$ & Datastream \\
\hline$C D S_{i t}$ & $\begin{array}{l}\text { 5-year CDS spread for government bonds. The } \\
\text { CDS spread is what the buyer pays the seller } \\
\text { as an annualized percentage of the notional } \\
\text { amount, until a credit event occurs or maturity } \\
\text { is reached. }\end{array}$ & Datastream \\
\hline LendingRate $_{i t}$ & $\begin{array}{l}\text { Difference in the household borrowing rates } \\
\text { between the corresponding country and } \\
\text { Switzerland. The borrowing rate is the } \\
\text { volume-weighted average interest rate on local } \\
\text { currency denominated loans to households for } \\
\text { purchasing or improving housing with a } \\
\text { maturity of five years or more. }\end{array}$ & $\begin{array}{l}\text { Datastream } \\
\text { (ITA, } \\
\text { ROM, } \\
\text { HUN, CZE, } \\
\text { BGR) and } \\
\text { central } \\
\text { banks. }\end{array}$ \\
\hline
\end{tabular}


Table A4: Definitions of the binary variables in the empirical analysis

\begin{tabular}{l|l|l}
\hline \hline Label & & \\
\hline CHF & 1 for Swiss franc mismatch index & $0 \mathrm{o} / \mathrm{w}$ \\
OTH & 1 for other foreign currency mismatch index & $0 \mathrm{o} / \mathrm{w}$ \\
HUN LCP & 1 for Hungary in conversion periods (2015 Q1 to end of sample) & $0 \mathrm{o} / \mathrm{w}$ \\
ROM LCP & 1 for Romania in conversion periods (2015 Q2 to end of sample) & $0 \mathrm{o} / \mathrm{w}$ \\
HRV LCP & 1 for Croatia in conversion periods (2015 Q4 to end of sample) & $0 \mathrm{o} / \mathrm{w}$ \\
LCP & 1 for conversion countries in conversion periods & $0 \mathrm{o} / \mathrm{w}$ \\
\hline \hline
\end{tabular}




\section{Recent SNB Working Papers}

2019-4 Andreas M. Fischer, Pınar Yeşin:

Foreign currency loan conversions and currency mismatches

2019-3 Benjamin Anderegg, Didier Sornette, Florian Ulmann: Quantification of feedback effects in FX options markets

2019-2 Katrin Assenmacher, Franz Seitz, Jörn Tenhofen: The demand for Swiss banknotes: some new evidence

2019-1 Darlena Tartari, Albi Tola:

Does the IMF Program Implementation Matter for Sovereign Spreads? The Case of Selected European Emerging Markets

2018-19 Samuel Reynard:

Negative Interest Rate, OE and Exit

2018-18 Hans-Ueli Hunziker, Christian Raggi, Rina RosenblattWisch, Attilio Zanetti:

The impact of quidance, short-term dynamics and individual characteristics on firms' long-term inflation expectations

2018-17 David R. Haab, Thomas Nitschka:

Carry trade and forward premium puzzle from the perspective of a safe-haven currency

2018-16 Gregor Bäurle, Elizabeth Steiner and Gabriel Züllig: Forecasting the production side of GDP

2018-15 Christian Grisse, Gisle J. Natvik:

Sovereign debt crises and cross-country assistance

2018-14 Thomas Lustenberger:

Has the American Output Growth Path Experienced a Permanent Change?

2018-13 Stephan Imhof, Cyril Monnet and Shengxing Zhang:

The Risk-Taking Channel of Liquidity Regulations and Monetary Policy
2018-12 Andreas M. Fischer, Henrike Groeger, Philip Sauré and Pinar Yeșin:

Current account adjustment and retained earnings

2018-11 Maxime Phillot, Rina Rosenblatt-Wisch: Inflation Expectations: The Effect of Question Ordering on Forecast Inconsistencies

2018-10 Alex Cukierman, Thomas Lustenberger: International Evidence on Professional Interest Rate Forecasts:

The Impact of Forecasting Ability

2018-9 Thomas Nitschka:

Did China's anti-corruption campaign affect the risk premium on stocks of global luxury goods firms?

2018-8 Andreas M. Fischer, Lucca Zachmann: Do the rich pay their taxes early?

2018-7 Basil Guggenheim, Mario Meichle and Thomas Nellen: Confederation debt management since 1970

2018-6 Lucas Marc Fuhrer, Basil Guggenheim and Matthias Jüttner: What do Swiss franc Libor futures really tell us?

2018-5 Barthélémy Bonadio, Andreas M. Fischer and Philip Sauré:

The speed of exchange rate pass-through

2018-4 Simone Auer, Christian Friedrich, Maja Ganarin, Teodora Paligorova, and Pascal Towbin: International Monetary Policy Transmission trough Banks in Small Open Economies 
